\title{
The Panama Canal - A Vital United States Interest?
}

\author{
A Monograph \\ by \\ Lieutenant Colonel Kevin Lee Kelley \\ United States Marine Corps
}

Advanced Operational Art Studies Fellowship

School of Advanced Military Studies

United States Army Command and General Staff College

Fort Leavenworth, Kansas

Academic Year 1999-2000

Approved for Public Release; Distribution is Unlimited

DTIC QUALITY ITEPEOTED 4 


\section{ABSTRACT}

\section{THE PANAMA CANAL - A VITAL UNITED STATES INTEREST?}

by LTCOL Kevin Lee Kelley, USMC, 40 pages.

The United States has held strong national interest in Panama since the 1840s. This interest was demonstrated by the building of the Panama Canal, its ensuing operation, and numerous military interventions into Panama concluding with Operation Just Cause in 1989. Control of the canal formally passed to Panama and the American military presence ended in 1999. By the 1977 Panama Canal Neutrality Treaty, the United States retained the right to intervene unilaterally if the canal or its neutral operation is threatened. Will the United States consider the Panama Canal a vital interest in the twenty-first century?

This monograph summarizes the United States historical involvement with the canal. Current economic, military and intangible American interests in the canal are analyzed. The most likely threats to the canal or American access to it are evaluated. These findings are considered against the backdrop of theories put forward by Alfred Thayer Mahan, Julian S. Corbett and Thucydides.

The monograph finds American economic and military interests in the canal have significantly depreciated over time. However, United States policy calls for global access and freedom of navigation to protect its vital interests. These principles combined with national prestige and honor will require the United States to consider the Panama Canal a vital interest in the twenty-first century. 
I. Introduction........................................................................................

II. United States Interests in the Panama Canal........................................... 6

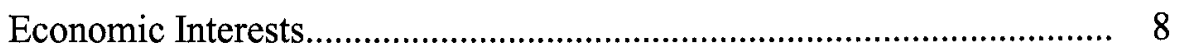

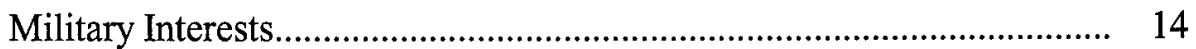

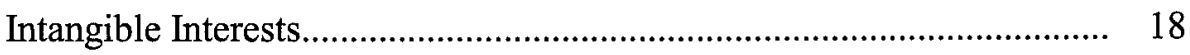

III. Threats to United States Interests in the Panama Canal............................ 21

Chinese Threat to the Panama Canal...................................................... 22

Colombia Rebel and Narco-Trafficker Threat to the Panama Canal....... 31

Panamanian Threat to the Panama Canal................................................

IV. Conclusions................................................................................. 37

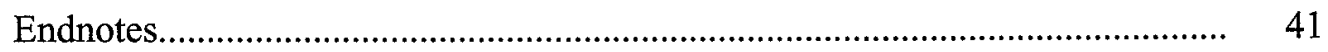

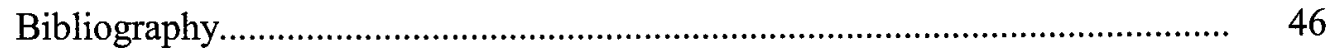




\section{CHAPTER ONE}

\section{INTRODUCTION}

Panama and the canal have been an important interest to the United States of America throughout the twentieth century. Five Unites States military interventions between 1903 and 1989 are clear evidence of these interests. ${ }^{1}$ In 1977, President Jimmy Carter and General Omar Torrijos, ruler of Panama, signed a treaty turning over complete control of the Panama Canal to Panama and withdrawing all United States military forces from the country by 31 December $1999 .{ }^{2}$ The two leaders signed the Neutrality Treaty also guaranteeing the neutrality of the canal for peaceful transit by vessels from all nations, which allows either nation to intervene unilaterally if that neutrality is threatened. ${ }^{3}$ Now that the United States has honored the provisions of the treaty it is fitting to examine the importance of United States interests in the canal in the twenty-first century. This is important because threats to the canal or United States access to it have been identified by authoritative sources. Should any of these threats come to fruition, is the Panama Canal important enough to the United States to warrant military intervention and possible war?

The purpose of this monograph is to explore the importance of the Panama Canal to the United States in the twenty-first century and to answer the research question as to whether the United States will consider it a vital interest? The issue will be examined in relation to the history, economic and military value, and intangible qualities associated with the canal. Conclusions will be based on these findings against the backdrop of thought provided by men such as Aldred Mahan, Julian Corbett and Thucydides. 
The United States took an interest in the Panama isthmus in the 1840s. The territory of California had just been won in war from Mexico. In addition, gold was discovered there and the rush for it was on. Travel to California by overland route was difficult, lengthy and dangerous. There was no transcontinental railroad and hostile indians continued to plague the area west of the Mississippi River. The sea route to California required passage round Cape Horn. In order to shorten the trip by thousands of miles and over a month of travel, many westward bound immigrants would debark on the Atlantic side of the isthmus and proceed overland to the Pacific side where they would embark on a different ship for final passage to California. Between 1849 and 1870, over 600,000 Americans crossed the isthmus enroute to California. Americans completed a railroad across the isthmus in 1849 to facilitate the westward movement. ${ }^{4}$

In 1846, the United States completed the Mallarino-Bidlack Treaty with the country of Colombia. The treaty reduced tariffs on American transit and pledged free international passage on the isthmus in exchange for the guarantee of continued Colombian sovereignty over Panama. During the years 1856-1902, the United States Navy assisted Colombia in putting down six revolts in Panama. The treaty provided the grounds for those interventions. ${ }^{5}$

Ferdinand De Lesseps, builder of Suez Canal fame, entered into an agreement with Colombia to build a sea level canal in 1879 . This concession was purchased for $\$ 10$ million and angered United States President Rutherford Hayes. He dispatched navy ships to demonstrate American presence off the Panama coast. He remarked the "policy of this 
country is a canal under American control...An interoceanic canal [will be] virtually a part of the coastline of the United States."

By 1889 , the De Lesseps-formed company went bankrupt and the canal was less than half completed. The French abandoned the project. The failed effort left behind as many as 22,000 dead Caribbean construction workers. According to Clifford Krauss, "The canal failure humbled France, forcing the French to question basic values of their society...The once-revered De Lesseps retired a broken, disgraced man--known to some as 'the pallbearer of Panama'."7 His words described the effects of failure on a world power and would imply that the stakes were raised for the United States in attempting to complete a canal.

Alfred Thayer Mahan wrote in 1889 that when a canal was completed the Caribbean would become "one of the great highways of the world". He goes on to note "The position of the United States with reference to this route will resemble that of England to the [English]Channel, and of the Mediterranean countries to the Suez route." He believed seapower would promote United States economic development as it earlier had done for England.

The benefits of a canal to a nation becoming a world power became evident during the Spanish-American War of 1898. A United States battleship, the USS Oregon, returned from the Phillipines to San Francisco and then required sixty-nine days to sail round Cape Horn to join the fleet near Cuba. A canal would have reduced the trip by 8,000 miles and forty days. As a world power, the United States would require the ability to reposition warships quickly to and from the Atlantic and Pacific Oceans. Congress and the public were ready to press forward with a canal. ${ }^{9}$ 
During 1902, The United States bought out the French investors of De Lessep's bankrupt company for $\$ 40$ million and attempted to complete a treaty with Colombia in 1902 to gain rights to build a canal. The treaty was approved by the United States Senate but was defeated by the Colombian congress. In 1903, the United States backed the rebellion of Panama who sought to secede from Colombia by blocking the approach of Colombian army units to quell the revolt led by General Esteban Huertas with an American warship, the USS Nashville. Soon afterwards, the United States entered into the Hays-Bunau-Varilla Treaty with Panama. For $\$ 10$ million initially and another $\$ 250,000$ annually the United States was granted sovereign authority over the ten mile wide canal zone. The United States committed $\$ 400$ million and 75,000 workers to the construction of the canal which was completed in 1914. 5,000 lives were lost during the construction mainly to disease. ${ }^{10}$

Resistance to and frustration with United States control of nearly ten percent of the country of Panama, the Canal Zone, was evidenced throughout America's control of the canal. Arnulfo Arias won election as Panama's president in 1940 based on his "pure" Panama platform which called for repatriation of the blacks and Chinese in the country. He also made friendly overtures toward Hitler and Mussolini while rebuffing American requests for more military bases and radar sites in the country. The National Police staged a coup against Arias, with American acquiescence, while he was vacationing in Cuba. The United States received the extra basing rights for 70,000 soldiers. Arias was reelected president in 1949 on a anti-American platform. He was overthrown, with American acquiessence again, in $1951 .^{11}$ 
In 1956, Egypt nationalized the Suez Canal. This was the spark to a prolonged nationalistic and anti-American movement. This movement started becoming quite active during May of 1958 when demonstrations by students resulted in nine deaths. The movement continued and riots occurred on 9 January 1964. Twenty Panamanians and four American soldiers were killed during the incident. ${ }^{12}$ Panama temporarily suspended relations with the United States with a demand for a complete revision of the treaty. Relations were restored but negotiations were slow in progress from Panama's view. In 1968, General Omar Torrijos deposed the elected government and established himself as dictator of Panama.

President Jimmy Carter and General Torrijos signed the Panama Canal Treaty and the Neutrality Treaty on 7 September 1977. The Panama Canal Treaty turned over complete control of the canal and all American military bases to Panama as of 31 December 1999. The Neutrality Treaty gives either nation the right to intervene if the canal or its neutrality is threatened and further gives the the United States Navy warships front-of-the-line privileges in times of emergency. ${ }^{13}$

Since 1903 the world has changed considerably and the interests the United States has in the Panama Canal have qualitatively diminished. Mass air travel, efficient railroad and highway networks have made both cargo and passenger travel throughout the continental United States more attractive. The trend toward very large merchant ships has reduced the value of the canal due to the limitations on the size of ships that can fit through the locks. United States Navy aircraft carriers cannot fit through the locks and the vulnerability of ships transitting the canal to hostile action lessens its strategic value. A trans-isthmus oil pipeline was completed in 1982 to transfer Alaskan oil from tanker 
ships on the Pacific side to tanker ships on the Atlantic side. Although the United States is the largest user of the canal, less than one percent of the Gross Domestic Product is involved. A 1994 joint study that is discussed in the following chapter recommended against making significant improvements to the canal.$^{14}$

The canal has some unquantifiable merit that Americans identify with. One of Ronald Reagan's campaign slogans concerning the canal during the 1976 primaries was, "We bought it, we built it, its ours." As crushing a blow as the French failure to build the canal, it was equalling uplifting to American spirits to have completed the canal. ${ }^{15}$ The canal turnover events leading up to 31 December 1999 and continuing congressional actions show the canal has a special place in American policy.

Numerous authoritative sources have identified threats to the Panama Canal or United States access to it as the twenty-first century begins. The three principal threats are Communist Chinese domination of the canal, Colombian rebels and narcotics traffickers and Panamanian inability to manage and maintain effectively a complex system like the Panama Canal. These proposed threats to the canal or continued American access to it have been articulated by too many authoritative persons (senators, congressmen, former secretaries of defense and chairmen of the joint chiefs of staff) with expert knowledge of the subject to ignore.

The United States has historically had important interests in the country of Panama and the canal. Those interests require examination for their relative merit in today's world in order to plan future United States policy in the region. Threats to American interests in the canal require analysis to plan strategies to counter them. The 
following analysis will form a basis of knowledge on which to decide if the canal is a vital American interest in the twenty-first century.

CHAPTER ONE ENDNOTES 
${ }^{1}$ Worldmark Encyclopedia of the Nations, Americas, (Detroit, MI: Gale Press, 1998) 290-291.

${ }^{2}$ Panama Canal Treaty, 7 September 1977.

${ }^{3}$ Neutrality Treaty, 7 September 1977.

${ }^{4}$ Clifford Krauss, Inside Central America, Its People , Politics and History, (New York: Simon and Schuster, 1991) 251.

${ }^{5}$ Ibid.

${ }^{6}$ Ibid.

${ }^{7}$ Ibid,252.

${ }^{8}$ A.T. Mahan, The Influence of Seapower upon History, (New York: Hill and Wang, 1957) 29.

${ }^{9}$ David McCullough, Path Between the Seas: the Creation of the Panama Canal, 1870-1914, (New York: Simon and Schuster, 1999).

${ }^{10}$ Ibid,254-255.

${ }^{11}$ Ibid,257.

${ }^{12}$ Ibid, 257-258.

${ }^{13}$ Panama Canal and Neutrality Treaties, 7September 1977. See also John Major, Prize Possession: the United States and the Panama Canal, 1903-1979, (London: Cambridge University Press, 1993) 349-350.

${ }^{14}$ South America, Central America and the Caribbean 1999, 7th Edition, (London: Europa Publications Ltd.) 529.

${ }^{15}$ Ibid, 255. 


\section{CHAPTER TWO}

\section{UNITED STATES INTERESTS IN THE PANAMA CANAL}

The United States has had continuing interests in the Panamanian Isthmus since the early 1840s. American interest started with a search for a shorter and safer route for immigration from the east to west coasts of the United States. As time went on, American interests centered on the trade and military advantages the canal offered the United States. The pride and prestige of the United States were put on the line initially to build the canal and then to keep it operating neutrally. On 31 December 1999 the canal passed out of the control of the United States to the Republic of Panama. The turnover has caused great debate over the relevant interests the United States has in the canal's continued neutral operations. This chapter examines United States economic and military interests in the canal and the effects if the canal were to be closed or United States access to it denied.

The Panama Canal is fifty-one miles in length and traverses the mountainous continental divide at 312 feet in elevation. The typical journey through the canal lasts approximately eight hours while ships are raised by means of three sets of locks over the continental divide and then lowered back to sea level to the opposite ocean. After waiting in line, the whole process of moving from one ocean to the other takes approximately twenty-four hours. The traffic moves in both directions simultaneously. ${ }^{16}$

The locks require enormous amounts of fresh water to operate them. Fifty-two million gallons of water are required for each ship passage. Gatun Lake, largest manmade lake at the time of canal construction, was constructed to fill these needs. The water is gravity-fed by culverts to the locks. 
The lock gates vary in size and weight, but all are massive. The locks are 963 feet long and 110 feet wide. The lock gates are sixty-five feet wide and seven feet thick, while their height and weight varies from forty-seven to eighty-two feet and 390 to 730 tons each. Their ingenious design allows them to be opened by a forty horsepower motor. The lock gates and their motors being used are original equipment. ${ }^{17}$

The Panama Canal cost the United States $\$ 350-400$ million and 5,000 lives to excavate 232 million cubic yards of dirt. ${ }^{18}$ Today, the canal collects $\$ 760$ million in annual revenues or an average toll per ship of $\$ 40,000 .{ }^{19}$ These few facts and figures allow the reader to comprehend the engineering feat accomplished in building and maintaining the Panama Canal.

The cost to build the canal and its revenues are easily quantifiable; United States continuing economic interests in the canal are not. There have been many changes since the 1914 opening of the canal. Travel throughout the United States, overland or by air, is much cheaper and faster. The United States has also developed a "land bridge" across the continent with its system of railroads and highways. The United States has developed a two-ocean navy capable of maintaining global superiority and there is no peer competitor. The United States economy has grown tremendously and its dependence on the canal is steadily decreasing. These factors require analysis to evaluate United States interests in the Panama Canal.

The canal accommodates approximately five percent of the world's ocean going trade. Over seventy percent of the ships transiting the canal have just left a United States port or are bound for one. Japan is the second largest customer of the canal. The canal has a capacity of passing thirty-nine ships per day. ${ }^{20}$ 
Specific to the United States, fifteen percent of goods imported into and exported from the United States pass through the canal. This includes forty percent of American grain exports. ${ }^{21}$ The busiest trade route using the canal is the United States east coast to the Far East and second busiest is the United States west coast to Europe. ${ }^{22}$

At first glance these figures suggest that a closure of the canal would have a major impact on the American economy. This should be kept in perspective by viewing the larger picture. According to the Central Intelligence Agency's World Factbook 1999, "The United States has the most powerful, diverse and technologically advanced economy in the world, with a per capita Gross Domestic Product of $\$ 31,500$, the largest among major industrial nations." The United States Gross Domestic Product in 1998 was \$8.511 trillion. ${ }^{23}$ The American goods flowing through the canal represent less than one percent of that Gross Domestic Product.

A large percentage of American agricultural exports, forty percent, flow through the canal. By sector, agriculture accounts for only two percent of the overall United States Gross Domestic Product. Rail transport of grain across the United States as opposed to using the canal might be more expensive and could hurt grain sales on the global market. ${ }^{24}$ However, the effects of a canal shutdown on American grain sales would have little effect on the overall United States economy.

The Panama Canal was built when the airplane was in its infancy in the development process. At the time, travel by ship was the only reasonable method of trans-oceanic travel. This fact made the canal a great advantage for those travelers who would otherwise have had to sail round Cape Horn. 
The airplane has since developed into the preferred mode of transportation for trans-oceanic travel. According to the Bureau of Transportation Statistics, in 1995 over ninety-seven million passengers traveled by air to and from the United States. Those traveling by ship were mainly vacationers seeking leisurely travel.

The ship remains the preferred mode of transport for freight over the airplane for trans-oceanic shipment. There was a thirteen percent increase during 1995 over 1994 in the amount of freight tons carried by United States and foreign airlines to and from the United States. This raised the total freight tonnage to 5.6 million tons. The figure pales when compared to the over one billion tons of freight moved by ships to and from the United States. $^{25}$

The United States is the world's largest trading nation. According to the Department of Transportation, the United States exports and imports twenty-five percent of the globe's merchandise trade in value annually, over $\$ 2$ trillion.. The size of the United States flagged Merchant Marine fleet has declined till it ranks as number fifteen in the world. However, productivity has increased forty-two percent over 1970 when the fleet ranked in the top five. The trend is clearly toward fewer, much larger and more efficient vessels. $^{26}$

This trend toward larger vessels has a definite impact on the future of the Panama Canal since its locks physically limit the size of ships that can transit the canal. The canal was built to accommodate the largest ships of the time during the early twentieth century. For most of the century, vessels were constructed with those size limitations in mind. The maximum size ship that can transit the canal is 965 feet in length, 106 feet in beam (width) and drafts 39.5 feet. The first clear cut examples of ships built disregarding the 
Panama Canal size limitations were the so-called super oil tankers and United States aircraft carriers.

The trend in shipping is toward mega ships according to the United States Department of Transportation's Office of Intermodalism. The average largest ship that can use the Panama Canal 896 feet in length, 106 feet in beam and drafts 39 feet. The larger ships being built today average 925 feet in length, 125 feet in beam and draft 45 feet. Those mega ships are simply too wide and draft too much water to use the canal.

In 1990, less than six percent of United States containerized cargo was handled by mega ships. The percentage is projected to increase to thirty percent by 2010 . Panama Canal capable ships will continue to move thirty-six percent of cargo bound for or leaving the United States. Currently, eighteen percent of new ships on order are mega ships. A large number of Panama Canal capable ships continue to be built, but their economic importance is declining. The Suez Canal can handle the much larger, modern ships. The Department of Transportation projects that trade routes will shift from the Panama Canal to the Suez Canal routes in response to rising Panama Canal tolls and the inability of the mega ships to transit it. ${ }^{27}$

The petroleum industry has found alternatives to the Panama Canal for its super tankers that are too large to make the transit through the canal. A Trans- Panama Oil Pipeline was opened in 1982 to carry Alaskan oil from tanker ships on the Pacific Ocean side of the canal to tanker ships on the Atlantic Ocean side of the canal for further transport to Caribbean Gulf or East Coast United States ports. The pipeline has a capacity of 830,000 barrels a day. In addition, the Alaskan Pipeline has been built to carry Alaskan oil to the continental United States. Another major pipeline was built in the 
United States in 1987 which reduced Panama's canal and its pipelines importance. The Celerosa Oil Company completed the “All American Pipeline" extending 1,971 miles between Santa Barbara, California and McCarney, Texas with a capacity of 300,000 barrels per day. The result has been a steady decline in oil crossing the Panama Isthmus. The pipeline alone has an annual capacity of 302.9 millions barrels, but in 1994 only 29.3 million barrels were pumped. ${ }^{28}$

Over seventy percent of the ships transiting the Panama Canal are bound for or departed from United States ports. As a result of cost efficiency or inability of the mega ships to transit the canal, many shippers have begun to use the "land bridge" across the continental United States as an alternative. For example, if the product is produced in New York and is bound for Japan it is shipped by train and highway to a West Coast port and loaded aboard shipping there for final transport to Japan. The same philosophy extends to imports from and exports to the entire globe. The United States government is studying ways to make the nation's port and transportation systems more efficient in response to the mega ship trend. ${ }^{29}$

The United States, Japan (second largest user of canal) and Panama jointly established a commission to study the canal's future in 1986. One consideration was to add another set of locks to increase taffic flow through the canal at a cost of $\$ 5$ billion. The report released in 1994 concluded no major improvements were needed until after 2010 because traffic was likely to increase by less than 1 percent per year. ${ }^{30}$ The costs involved in building a new canal or replacing the current locks with larger ones would be cost prohibitive in view of these facts. 
The economic effects of the Panama Canal are much greater on the countries of South America. Over forty percent of the the seaborne exports of Ecuador, Peru and Venezuela pass through the canal. ${ }^{31}$ There is no "land bridge" transportation system in South America to use as an efficient and cost effective alternative should they lose access to the canal.

The United States has traditionally had military interests in the Panama Canal. These interests have been protected through numerous interventions and basing of United States armed forces within the Canal Zone. The basing of American military personnel and equipment ended by treaty on 31 December 1999. However, the United States retains the right by the same Panama Canal and Neutrality Treaties of 1977 to intervene militarily if the canal or its neutral operation is threatened. Time, technological advances and changing world relationships may have lessened those interests the United States has in the canal.

One of the leading proponents for the Panama Canal was an American military officer, Captain Alfred Thayer Mahan, Unites States Navy. He professed that seapower would provide the means for the United States economy to blossom with global trade. He wrote,

If one be made, and fulfil the hopes of its builders, the Caribbean will be changed from a terminus, and place of local traffic, or at best a broken and imperfect line of travel, as it now is, into one of the great highways in the world. Along this path a great commerce will travel, bringing the interests of the other great nations, the European nations, close along our shores, as they have never been before. With this it will not be so easy as heretofore to stand aloof from international complications. The position of the United States with reference to this route will resemble that of England to the Channel, and of the Mediterranean countries to the Suez route. ${ }^{32}$

The Panama Canal was considered one of the world's twelve most important strategic maritime passages by the United States Naval Ocean Reseach and Development Activity during the Cold War. It maintained that importance because it allowed the 
United States to quickly reposition forces and supplies while engaged in a possible world war. ${ }^{33}$ Since the Soviet Union's collapse, the global challenges and competitors faced by the United States have changed considerably.

The Clinton administration has gone on record considering global access and freedom of navigation throughout the world's seas as essential to the well being of the United States. The administration has actively sought to safeguard those principles.

Our need for strategic mobility to deploy our forces overseas is one of the primary reasons we are committed to gaining Senate advice and consent to ratification of the Law of the Sea Convention. Need for this treaty arose from the breakdown of customary international law as more and more nations unilaterally declared ever larger territorial seas and other claims over the oceans that threatened the global access and freedom of navigation that the United States must have to protect its vital national interests. In addition to adding the certainty of the rule of law to an area critical to our national security, the treaty protects our economic interests and preserves our leadership in global ocean policy. The Law of the Sea thus buttresses the strategic advantages that the United States gains from being a global power. ${ }^{34}$

These statements clearly intimate the national resolve of the United States to use military power to protect freedom of navigation and global access throughout the the world's seas as a national interest.

Alfred Mahan argued the Panama Canal is central to United States security because of its geographic position to this strategic chokepoint. The United States remains the dominant power in the region that this sea line of communication passes through with trade from the Americas, Asia and Europe. In naval warfare, control of friendly sea lines of communication also translates into controlling the enemy's sea lines of communication since they normally are either parallel or the same. In the case of chokepoints like the Panama Canal they are the same. ${ }^{35}$

The world's sea lines of communications may be changing in importance and if closed would merely cause temporary friction until traffic was re-routed. As noted earlier the United States Department of Transportation is predicting a major shift in traffic from 
the Panama Canal trade route to the Suez Canal trade route as a result of inability to accomodate mega ships and rising tolls. The United States Naval War College's John Hattendorf, a professor of maritime strategy, says, "The canal is useful and convenient and saves us some money, but is no longer strategically essential." During the period of January through November 1999, only forty United States Navy ships transited the Panama Canal out of a fleet of 321 . Those ships were on routine movements to ships maintenance facilities instead of carrying out tactical missions. The last United States aircraft carrier capable of transiting the Panama Canal, USS Oriskany, was decommissioned in 1976. More recently, no United States Navy ships transited the Panama Canal in support of either Desert Shield or the Kosovo Operations. These facts support the lessening strategic importance of the Panama Canal. ${ }^{36}$

The United States Navy's largest capital ships are incapable of passing through the Panama Canal. The oldest class of aircraft carriers in current service, USS Kitty Hawk class, have a length of 1062 feet and a beam (width) of 130 feet. The largest aircraft carrier is the USS Enterprise with a length of 1101 feet and beam of 133 feet. The most modern and current design class of aircraft carriers, USS Nimitz class, has a length of 1092 feet and beam of 134 feet. The maximum size ship that can transit the Panama Canal has a length of 965 feet and beam of 106 feet. No United States aircraft carrier could, even if desired, fit through the Panama Canal. ${ }^{37}$

The modern day United States Navy is built around the aircraft carrier. "The aircraft carrier continues to be the centerpiece of the forces necessary for forward presence. Whenever there has been a crisis, the first question has been, Where are the carriers?" Admiral Jay Johnson, Chief of Naval Operations, said, "The Navy is built 
around twelve carrier battle groups and twelve amphibious ready groups as its primary means of power projection. ${ }^{38}$ From these authoritative source comments it is obvious that the aircraft carrier is central to United States naval strategy.

Deployment packages of ships are task organized around aircraft carriers into groups. These groups do not routinely separate and each ship within the group has a role in the defensive and offensive missions assigned to the carrier battle group. This eliminates the use of the Panama Canal by the other smaller navy ships in an aircraft carrier battle group because it would make the group or some of its ships vulnerable to hostile action while they were separated.

Mahan's interest in seeing the Panama Canal built at the beginning of the twentieth century coincided with the United States emergence as a global power. At the time, the United States had a "one ocean navy" which required rapid transit for its ships to crisis locations across the globe. An excellent example was the case of the USS Oregon in 1898 which had to redeploy from the Phillipines naval actions against Spain Cuban waters. This redeployment required 69 days, 40 of which would have been done away with if there had been a Panama Canal short cut from the Pacific Ocean to the Atlantic Ocean.

Since the Spanish-American War the United States has fought two world wars and a global cold war. The United States has developed a balanced "two ocean navy", Atlantic and Pacific Fleets, capable of addressing crisis points independently. When support is required from the other fleet, the United States Navy does not utilize the Panama Canal as was demonstrated by the Persian Gulf and Kosovo conflicts. 
In addition to the United States economic and strategic interests in the Panama Canal, there are also certain unquantifiable intangible interests. Thucydides believed that nations go to war for interests, out of fear and for honor. ${ }^{39}$ The United States would appear to have considerable intangible interests in the continued neutral operation of the canal and United States access to it. This is evidenced by United States insistance on the unilateral right to intervene militarily if either is threatened by the Panama Canal and Neutrality Treaties of 1977.

American emotional attachment to the canal was capitalized on by Ronald Reagan during his 1976 presidential election campaign. The controversial Panama Canal Treaty negotiations were a major campaign issue. He said, "We bought it, we built it, its ours." The Senate debate over the 1977 Treaties was the second longest in the United States history and was the first completely radio broadcasted debate in history. ${ }^{41}$ The historic turnover of the Panama Canal to the Republic of Panama was preceded by huge disagreement by current and former government and military officials over the wisdom of completing the turnover and its implications to national security and interests. The issues were debated during House and Senate committee hearings during the Fall and Winter of 1999. ${ }^{42}$

The United States is the dominant power and leader of the world. The American people believe the United States can accomplish things like putting men on the moon or building the Panama Canal when no other nation is able. That belief in United States power started with the completion of the canal after the dominant power, France, failed in the endeavor. ${ }^{43}$ The loss of access to the Panama Canal could only result in a blow to United States national prestige and honor. 
Mahan would argue that as a maritime nation, it is imperative for the United States continued economic success to retain control of the world's sea lines of communication. This will enable the United States and its allies to retain freedom of navigation and access to global commerce. These views are summed up by Walter McDougal who writes, "Surely free trade and freedom of the seas are vital interests, and ones the United States ought to promote and, in the latter case, defend with grit because no other navy is up to the job."

An opposing view of the modern world would argue that the traditional sea lines of communications and the strategic chokepoints of the world's seas have been overcome by technology and the global economy. A primary example used would be the Suez Canal closure, from 1967 through 1975, without major disruption of the world's commerce. Shipping simply found other routes. Harlan Ullman, naval strategist at the Brookings Institute says, "We are entering a transitional period, at the end of the twentieth century, the choke points are moving to cyberspace and economic markets."

United States economic and strategic interests in the Panama Canal have quantifiably been reduced by time and technological advances. For the present and foreseeable future the United States vital interests are linked to freedom of navigation and global access to sea lines of communication. As earlier noted that is offical United States policy articulated in the National Security Policy of 1998. Continuing United States vital interests in freedom of navigation of the world's seas and the United States geographic and historical relationships to the Panama Canal will make it a vital interest to the United States in the twenty-first century. 
This monograph's analysis of the Panama Canal has determined it to be a vital interest of the United States in the twenty-first century. The next task is to judge if there is a credible threat to the canal or American access to it. The following chapter will analyze the alleged threats currently associated with the canal.

\section{CHAPTER TWO ENDNOTES}

${ }^{16}$ United States Marine Corps, Panama Country Handbook (1999). 
${ }^{15}$ Denison Kitchel, The Truth About the Panama Canal, (New Rochelle, NY: Arlington House, 1978) $140-141$.

${ }^{18}$ Ibid,255.

${ }^{19}$ Carla Anne Robbins, "Why Should The U.S. Even Care Its About To Lose Panama Canal?, Wall Street Journal, (10 December 1999).

${ }^{20}$ South America, Central America and the Caribbean 1999, 7th Edition, (London: Europa Publications Ltd.) 529.

${ }^{21}$ Caspar W. Weinberger, "Panama, the Canal and China", Forbes, (4 October 1999) 41.

${ }^{22}$ Panama Canal Commission, "Maritime Operations", URL:<http://www.pancanal.com>, accessed 27 August 1999.

${ }^{23}$ Central Intelligence Agency, "The World Factbook, 1999", URL: $<$ http://www.odci.gov/cia/publications/factbook/us.html>, accessed 21 December 1999.

24 “A Reluctant Farewell”, Cleveland Plain Dealer, (26 November 1999).

${ }^{25}$ United States Bureau of Transportation Statistics, URL: $<$ http://www.bts.gov/oai/international/junesum.htm $>$, accessed 30 December 1999.

${ }^{26}$ United States Department of Transportation, URL: $<$ http: $/ /$ www.trans-inst.org $/ 1 . h t m l>$, accessed 30 December 1999.

${ }^{27}$ United States Department of Transportation, Office of Intermodalism, "The Impacts of Changes in Ship Design on Transportation Infrastructure and Operations", (February 1998), URL: $<$ http://www.bts.gov/ntl/subjects/ships.html, accessed 30 December 1999.

${ }^{28}$ South America, Central America and the Caribbean, 1999, 7th Edition, (London: Europa Publications Ltd) 529.

${ }^{29}$ United States Department of Transportation, Office of Intermodalism, "The Impacts of Changes in Ship Design on Transportation Infrastructure and Operations", (February 1998), URL:<http://www.bts.gov/ntl/subjects/ships.html, accessed 30 December 1999.

${ }^{30}$ South America, Cenral America and the Caribbean, 1999, 7th Edition, (London: Europa Publications Ltd.) 529.

${ }^{31}$ Carla Robbins, "Why Should the United States Even Care Its About To Lose Panama Canal?", Wall Street Journal, (10 December 1999).

${ }^{32}$ A.T.Mahan, The Influence of Seapower upon History, (New York: Hill and Wang, 1957) 29.

${ }^{33}$ George E Stanford Jr, "Strategic Passages", Naval Ocean Research and Development Activity. Requirements and Assessments Office, (October 1987).

${ }^{34}$ The White House, National Security Strategy for a New Century, (October 1998) 27.

${ }^{35}$ Julian S. Corbett, Some Priciples of Maritime Strategy, (Anapolis, Maryland: Naval Institute Press, 1988) 322. 
${ }^{36}$ Carla Robbins, "Why should the U.S. Even Care Its About to Lose Panama Canal?", Wall Street Journal, (10 December 1999).

${ }^{37}$ United States Navy, URL: $<$ http://www.chinfo.navy.mil/navypalib/factfile/ships, accessed 30 December 1999.

${ }^{38}$ Admiral Jay Johnson, CNO of United States Navy, Address to Command and General Staff College, given at Ft Leavenworth, Kansas on 7 January 2000.

${ }^{39}$ Thucydides, History of the Peloponnesian War, (London: Penguin Books, 1972).

${ }^{40}$ Linda Robinson, "Yankees Go Home, Finally", U.S. News and World Report, (6 December 1999).

${ }^{41}$ J. Michael Hogan, The Panama Canal in American Politics, (Champaign, Illinois: Southern Illinois University Press, 1986) 7.

${ }^{42}$ Steven Mufson, "In Panama, Ports in a Storm", Washington Post, (8 December 1999).

${ }^{43}$ Clifford Krauss, Inside Central America, its People, Politics and History, (New York: Simon and Schuster, 1991) 255.

${ }^{44}$ Walter A. McDougal, Promised Land, Crusader State, (New York: Houghton Mifflin Company, 1997) 213.

${ }^{45}$ Justin Brown, "World Chokepoints are Moving from Sea to Air", Christian Science Monitor, (15 December 1999). 


\section{CHAPTER THREE}

\section{THREATS TO UNITED STATES INTERESTS IN PANAMA CANAL}

The previous chapters discussed the types of interests the United States has historically and currently holds in the Panama Canal. Leading up to and following the historic turnover of the canal from the United States to Panama there has been considerable controversy as to the credibility and likelihood of threats to either the canal itself, its future neutrality or continued United States access to the canal. Three types of threats to the canal, or United States interests in it, have received most of the attention from authoritative sources and the media. ${ }^{46}$ This chapter will examine critically these assertions. The credibility of these threats has a direct link to the relevance of the priority of the Panama Canal to United States interests on a regional and global scale.

The first threat involves a domination of the canal and the nation of Panama by the Peoples Republic of China. The communist Chinese have business interests on a global scale. One of the hotbeds of their commercial interests are the port operations at the Panama Canal. The concern has been voiced that the Peoples Republic of China will eventually fill the power vacuum left by the United States in Panama, by the canal's turnover, and use their influence to undermine United States interests in the Western Hemisphere, or during a future military crisis deny the United States access to transit the canal.

The second main threat proposed emanates from the rebels in neighboring Colombia and the narco-traffickers operating from that country. The country of Colombia has been destabilized by the rebels and has had to concede control of large portions of the country to the rebels. The rebels are now tied to the narco-traffickers of 
Colombia who are engaged in a undeclared war with the United States. Panama has no army to defend its extensive and remote border with Colombia. The rebels and narcotraffickers can cross the border with impugnity. There is a concern the country of Panama will also be destabilized and the narco-traffickers will dominate the government of Panama and its canal operations. ${ }^{47}$

The final threat to be analyzed is Panama's alleged inability to operate effectively and efficiently the canal over the long term future. The government's record of operating other services has not been good. The canal is an extremely complex system that utilizes very old equipment. The costs and extent of maintenance required to maintain its current level of operations is rising. There is considerable debate on the ability of the Panamanians to fund adequately these maintenance costs and attend to the costly social needs of its citizens as well.

The alleged threat posed by the Peoples Republic of China is not an overt military strike scenario. The assertions center on the Peoples Republic of China using its extensive network of international businesses to gain de facto control over the Panama Canal and Panama itself over an extended time period. These same business interests would be used to erode United States influence throughout the region. This threat has been sounded by numerous experts and also rebutted by equally impressive authorities.

The most vocal proponents of the Chinese threat to the canal have been President Reagan's Defense Secretary, Caspar Weinberger, United States Senate Majority Leader, Trent Lott, United States Congressman Dana Rohrabacher, and former Chairman of the Joint Chiefs of Staff, Admiral Thomas Moorer (Retired). Authoritative sources who claim there is no threat posed by the Peoples Republic of China are President Clinton and 
his administration, the Commander in Chief of United States Southern Command, General Charles Wilhelm, President Nixon's Secretary of State, Henry Kissinger, Panamanian President Mireya Moscoso and former United States Ambassador to Panama, Ambler Moss. The list of notable current and former policy makers on both sides of the argument supports analysis of the Chinese threat to the canal and United States access to it.

One of the primary indicators of the Communist Chinese threat to the canal is the port concession contract won by a major Hong Kong corporation in 1997, according to proponents of the theory. Hutchison Whampoa, Ltd's bid was selected by Panama to operate the ports of Cristobal and Balboa for twenty-five years with an option for another twenty-five years. These ports are at the Atlantic and Pacific entrances of the canal. The bidding process was strongly contested as unfair by United States Ambassador William Hughes. $^{48}$

Former Secretary of Defense Caspar Weinberger wrote, "The biggest threat to the canal is that in 1997 Panama granted a subsidiary of Hong Kong-based Hutchison Whampoa, Ltd a twenty-five year concession to operate the canal's Atlantic and Pacific entrances at Balboa and Cristobal. (The United States claims the contract is improper because we entered a higher bid, but nothing has been done about this.)" ${ }^{49}$ He went on further to warn that it would not be logical for China to "pass up a chance to acquire a major foothold in one of the world's three major chokepoints - especially if it can be done with little cost or risk." Weinberger has characterized the Clinton Administration's approach to Panama as "why worry". He also believes the canal is important to United States security because it saves "millions of hours and dollars each year by having our 
naval vessels and supplies for all military services sail through the canal rather than around Cape Horn."

United States Senator Trent Lott, Majority Leader, sent a letter to Secretary of Defense William Cohen raising his concerns over the Communist Chinese threat on 1 August 1999. Senator Lott, Mississippi Republican, wrote,

This administration is allowing a scenario to develop where United States national security interests could not be protected without confronting the Chinese Communists in the Americas. United States naval ships will be at the mercy of Chinese-controlled pilots and could even be denied passage through the Panama Canal by Hutchison, an arm of the Peoples Liberation Army. In addition, the Chinese Communist Party will gain an intelligence information advantage by controlling this strategic chokepoint. It appears we have given away the farm without a shot being fired. ${ }^{51}$

One of the most vocal proponents of the Communist Chinese threat has been United States Congressman Dana Rohrabacher, California Republican. He is a member of the House of Representatives subcommittee on Asia and the Pacific. He has written, "The acquisition of the primary ports on the Atlantic and Pacific coasts of the Panama Canal has enabled Communist China rapidly to expand its economic, political and intelligence presence in Latin America and the Caribbean region. This expanding presence on the key strategic chokepoint of the Americas by a company beholden to a power hostile to the United States poses a serious national-security threat to Americans." He also casts doubt on the port bidding process in which Hutchison Whampoa, Ltd gained control of Cristobal and Balboa ports. He wrote, "I have official documents showing that consortiums that included American companies outbid the Chinese company in the formal ports-privitization auction. Yet, when the corrupt Panamanian regime unfairly changed the rules to the advantage of the Chinese, neither the White House or the Panama Canal Commission submitted a meaningful protest." Congressman 
Rohrabacher's comments portray his beliefs that Hutchison Whampoa, Ltd is controlled by the Communist Chinese regime, that the bidding process was corrupt and that the Chinese are using their control of the ports to increase their influence in the region. Congressman Rohrabacher believes the Communist Chinese are using their economic power as a form of assymetrical warfare against the United States. One of the proofs he sights is a recently published book in the Peoples Republic of China called Unrestricted Warfare. It was written by two senior colonels in the Peoples Liberation Army, Qiao Liang and Wang Xiangsui. The book was endorsed by at least some of the senior leadership and has received widespread attention. ${ }^{52}$ Rohrabacher comments, China's Peoples Liberation Army, or PLA, does have a defined military strategy for confronting the United States. Its called assymetrical or unrestricted warfare. An important new book, titled Unrestricted War, published by the PLA in 1999, is widely read and discussed by China's military elite. The authors of Unrestricted War advocate that the tactics for a less developed country to attack and defeat a superpower should include terrorism, drug trafficking, computer hacking and financial warfare. This warfighting strategy is enhanced by China gaining a foothold in Panama. Pointedly, in an interview published on June 28 in a Beijing newspaper, the authors of Unrestricted War cite Panama as a fertile example for no-limits war. They state, 'A small country like Panama would have a chance to exploit [the United States]. It could use a nolimits strike [at the canal] to cause America trouble causing chaos to the United States financial system.

Congressman Rohrabacher warns the United States, "If we do nothing, I can guarantee you that within a decade a Communist Chinese regime that hates democracy and sees America as its primary enemy will dominate the tiny country of Panama and the Panama Canal. One of the world's most strategic chokepoints will be under the control, or at least under the domination, of a hostile power., 53

Admiral Thomas Moorer, United States Navy (Retired), former Chairman of the Joint Chiefs of Staff, contends the Communist Chinese are a threat to gain control of the canal and as a result threaten United States security. He was part of a group that delivered 250,000 petitions at the Unites States Capitol building urging congressional 
investigation of Panama's port concession grant to Hutchison Whampoa, Ltd. He believes the corporation has direct ties to the Communist Chinese ruling regime and the Peoples Liberation Army. He has said, "I call the 31st of December (1999) 'doomsday', and so I say; Wake up America and put a stop to this." Other comments include, "We built it, we paid for it, we use it. We want to make sure the Communist Chinese don't gain control of it." He claims, "the Chinese are in a position today to secrete missiles into Panama and use Panama as a launching point for missiles to attack the United States. We are blindly going along with the terms of this treaty and, in effect, surrender the most important seagoing gateway in the world." $\$ 4$

There is substantial concern that the Communist Chinese are already using their economic influence in Panama to immigrate illegally Chinese into the Americas and the United States via Panama. Over 15,000 illegal Chinese immigrants have entered Panama in the past several years. ${ }^{55}$ The Peoples Liberation Army possibly utilizes these immigrants to build intelligence networks. Stanislav Lunev, a former Soviet military intelligence colonel based in Beijing who defected to the United States, made these comments concerning Communist Chinese activities in Panama.

\footnotetext{
One of the primary factors accounting for the success of Chinese intelligence is the exploitation of...the vast immigration of Chinese to communities worldwide. The Chinese intention to develop oceangoing capabilities for its navy is well known. But the Chinese navy does not yet have such worldwide capabilities at a time when it needs to have information about the perimeter of the Pacific region. This is the reason that Chinese entrepreneurs are actively in the market for abandoned port facilities in strategic locations. ${ }^{56}$
}

The Communist Chinese are developing their naval capabilities as best evidenced by their building of a new intercontinental ballistic missile submarine. The missiles on this strategic submarine will reportedly be armed with warheads developed from stolen 
United States secrets. It is conjectured that this new military capability combined with control of the Panama Canal would be used as a counterweight to United States intervention during a future Communist Chinese invasion of Taiwan. ${ }^{57}$

The purported ties Hutchison Whampoa, Ltd has with the Communist Chinese regime and the Peoples Liberation Army have more substance than the corporation's home base of Hong Kong. The company chairman, Li Ka-shing, has strong economic ties to the Chinese Communist Party and the Peoples Liberation Army. He is a board member of the China International Trust and Investment Corporation, which serves as the Chinese government's main investment arm and is involved in marketing Chinese arms. He has been reported to be involved in many Communist Chinese government and commercial interests on a global basis. It should be noted that this same corporation operates seventeen other facilities around the world, including three in Great Britain. ${ }^{58}$ The claims that Hutchison Whampoa, Ltd is a front for the Communist Chinese regime or the Peoples Liberation Army have not been conclusively proven beyond Li Ka-Shing's membership on the above mentioned board.

The United States Senate Armed Forces Committee held hearings, beginning 15 October 1999, on Chinese activities in Panama. These hearings were conducted at the request of Senate Majority Leader, Trent Lott. The witnesses represented a cross section of opinion debating whether Chinese activities in Panama constitute a threat to either the canal or Panama itself. One of the authoritative witnesses was the current Commander in Chief of the United States Southern Command, General Charles E. Wilhelm, United States Marine Corps. Panama and the canal fall within his area of responsibility. He believes the Communist Chinese pose no direct military threat to the canal or Panama. 
However, his comments could point to a possible indirect threat. He stated he believes the Peoples Republic of China uses businesses for military purposes. An intelligence report released by Southern Command said Chinese activities in Panama are "less a local threat to the canal and more a regional threat posed by expanding Chinese influence throughout Latin America." 59

President Clinton and his administration have vigorously denied any Communist Chinese threat to the Panama Canal or United States interests in the canal. The president has openly dismissed the Chinese threat to the canal. Speaking on the topic he said,

The Hong Kong company which got the concession to operate the ports will be responsible for loading and unloading ships. They also do this in three or four ports in Great Britain. Its one of the biggest companies in the world that does this. The managing director is British. Most of the employees will be Panamanian. So I feel comfortable that our security and commercial interests can be protected under this arrangement. ${ }^{60}$

Former President Jimmy Carter, who signed the Panama Canal and Neutrality Treaties, says the claims of Communist Chinese threat by way of Hutchison Whampoa Ltd's port contract "is completely false and misleading but is typical of what those people have done to distort the truth since even before I was president." ${ }^{\text {61 }}$ Former Secretary of State for President Nixon, Henry Kissinger, recently said, "We should not invent imaginary dangers of foreign influence threatening the security of the canal. ${ }^{, 62}$ Ambler Moss, United States Ambassador to Panama (1978-1982), dismisses the Communist Chinese threat to the canal. He further believes the Taiwanese pose a counter-weight to their influence for two reasons. Panama and many other Latin American countries still recognize Taiwan as the legitimate China and because of the many Taiwanese businesses and commercial interests in Panama, including a container port operation. ${ }^{63}$ 
The subsidiary of Hutchison Whampoa, Ltd that gained the port contracts for Cristobal and Balboa is Hutchison Port Holdings. Its president, John Meredith, maintains that fears of threats to United States security from his company's operations in Panama are groundless and that the company has no links to the Peoples Liberation Army. In response to the allegations of being a front for the Communist Chinese regime he said, "We are a commercial enterprise that is accountable to our stockholders... We cooperate with governments around the world, but do not serve as a front or tool for any of them." Hutchison Port Holdings has no Chinese employees in Panama. The president is British, his assistant is American and ninety-seven percent of the employees are Panamanian. ${ }^{64}$

The container port operations at Cristobal and Balboa that Hutchison Port Holdings administers should be kept in perspective. Ships transiting the canal are not required to utilize either of the ports and the Panama Canal Authority, an independent governing agency, controls transits and the pilots who guide ships through the canal. The Manzanillo International Terminal accounts for ninety percent of the cargo loaded or unloaded in Panama. It is operated by a United States company called Stevedoring Services of America. The second largest port, the Colon Container Terminal, is operated by a Taiwanese firm. Both Hutchison Ports combined account for less than five percent of the traffic. ${ }^{65}$

Communist China is the third largest user of the canal, behind the United States and Japan. It is also the largest goods provider into Panama's Free Zone, over $\$ 2$ billion per year. Three thousand of the 14,000 Panamanian flagged merchant ships are based in Hong Kong. Those ships registries are a large source of income to the Panamanian government. It can be argued that Chinese economic interests in Panama will give them 
tremendous political clout within the country. However, these same economic interests require a smoothly operated canal. ${ }^{66}$

Newly elected Panamanian President Mireya Moscoso has personally sought to reassure the United States on the continuing neutral operation of the canal under Panama's control. She said, "Our final objective is to guarantee safe, efficient and uninterrupted operation of the canal to satisfy our customers and to benefit our country." To that end, a constitutional amendment was enacted in 1994 making the Panama Canal Authority an autonomous body. This step was taken to reduce any effect that corrupt government officials might have on canal operations. ${ }^{67}$

A different type of threat emerges from Panama's southern border with Colombia. The nation of Colombia has had an active civil war ongoing for over thirty years that the Colombian government has been unable to quell. Colombia is also home to some of the world's largest narco-traffickers. Their main export to the United States is cocaine. ${ }^{68}$ The United States has actively been engaged in a so-called "Drug War" to curtail the entrance of the drugs into its sovereign territory and to destroy the coca agricultural, processing and distribution base abroad. The United States has been engaged in its Colombia efforts with the cooperation of the Colombian government. This has resulted in an alliance between the Colombian rebels and the narco-traffickers.

In effect, the revolution in Colombia is being financed by the drug trade. The rebels receive the best equipment that a seemingly endless source of money can buy and the narco-traffickers receive the protection of the rebels to carry on their profitable trade. The rebels now control approximately seventy percent of the Colombian countryside. In addition, right wing paramilitary groups have developed throughout the country to fight 
the rebels and narco-traffickers on a local level. Their tactics and motives are often suspect. The United States is heavily involved in assisting the Colombian government's efforts against the narco-traffickers, but does not take an active role against the rebels and paramilitary groups as they are seen as internal insurgencies. These groups freely flow over the remote, jungle border into Panama.

Panama serves as a major transshipment point for cocaine and its major banking institutions have served as major drug money laundering facilitators. The country of Panama has no armed forces, only a police force of 14,000 officers. It has proven extremely difficult for the government of Panama to safeguard its borders or its business institutions from the destabilizing threats posed by the Colombian rebels, narcotraffickers and paramilitaries. ${ }^{69}$

Prior to the turnover of the canal to Panama, the United States conducted extensive counterdrug operations from its bases in the Panama Canal Zone. An attempt by the United States in 1998 to negotiate for an American-led antidrug center on Howard Air Force Base in Panama failed. Panamanian President Mireya Moscoso has made it clear in statements, issued in both Washington D.C. and Panama, that Panama will not allow basing of United States forces in Panama. She said, "I emphasized that the military relationship ends on 31 December [1999]. We do not want more military bases within our country." She made these comments following a visit with President Clinton. ${ }^{70}$

The rebels and narco-traffickers cross the Panamanian border routinely and probably use Panamanian territory for their operations. Carlos Castano, a right wing paramilitary leader in Colombia, has recently said, the Panamanian national guard was "working in open connivance with the rebel group in the border zone" to smuggle arms 
and drugs and that now his forces would regard the Panamanian forces as a "military objective". President Moscoso has promised increased police support in the border area but progress is slow. The Roman Catholic bishop to the area, Romulo Emiliani, said "the only way to prevent insurgents from entering Panama is with arms, if this is not done, instability will spread throughout the country.,71

Recently, Colombian rebels hijacked two private charter helicopters from Panama with six female tourists. The tourists were bound and left behind on a Caribbean island. The rebels took the helicopters claiming they needed them to airlift injured rebels in western Colombia. Crossborder kidnappings are commonplace. The motive is ransom money. The United States Southern Command considers the rebel and narco-trafficker operations to be a regional issue which Panama may not be capable of handling on its own. $^{72}$

In reference to the rebel incursions over the border, Norman Bailey, a former National Security Council official, said "Panama has no capacity to control it. The possibilities of sabotage to the canal are enormous." In reply, the United States State Department aide for Latin America said the canal was not vulnerable because of the barrier formed by the thick Darien jungle. ${ }^{73}$

The Colombian rebels, financed by the narco-traffickers, have the ability to threaten the canal. The motivation to threaten the canal is disputed by several experts. If the rebels posed an overt threat to the canal it would be an invitation to the United States to intervene in the region. This action is allowed by the Neutrality Treaty. ${ }^{74}$

The final threat to the canal is the questionable ability of a developing nation such as Panama to effectively operate and maintain an old and complex system as the Panama 
Canal. The country has tremendous internal pressure to improve the quality of life for its population. The age and the limited capacity of the canal have impacted on its ability to be the "cash cow" the Panamanians expected. The canal and its related shipping activities have been the basis for growth in the economy. ${ }^{75}$ There is a concern that Panama will defer maintenance on the canal and use the toll revenues to fund other domestic agenda projects.

Panama lost 3,000 jobs and an annual cash infusion of $\$ 350$ million when the United States military bases closed. They have an overloaded road network, underfunded schools and an inadequate sewage system. The International Monetary Fund estimates to cleanup the Bay of Panama and construct a new sewage treatment facility will cost over $\$ 500$ million. The annual government budget for 1997 was $\$ 2.4$ billion total. The country also has a $\$ 5.8$ billion debt burden. The hope for economic relief has traditionally been the canal and its revenues.

The Panama Canal operated at or near capacity for 1998 , which meant 14,000 (39 per day) ships transited the canal. Each ship requires fifty-two million gallons of fresh water gravity fed from Lake Gatun. The water requirements limit the daily capacity to thirty-nine ships. The Panama Canal Authority is considering an upgrade to the canal which would increase income from additional transit capacity. The project would add another set of locks and would require doubling the water consumption. This would mean damming several major rivers and enlarging the size of the canal's watershed to encompass up to fifteen percent of Panama. The projected cost is $\$ 8$ billion. The United States government in an earlier study concluded such a project was not warranted because of low projected shipping demand forecasts through $2010 .^{76}$ 
Since the canal is operating at maximum capacity, there are two options to substantially increase profits from it. The tolls paid by ships to transit can be raised. The average toll per ship was $\$ 40,000$ when the canal operated under United States control. Increased tolls may cause shippers to use alternative routes or means of shipment. The second option is to defer maintenance on the canal. Panama received $\$ 134$ million in profits out of a total of $\$ 760$ million in revenue for 1998 . The rest went toward the canal's operating and maintenance expenses. They project the profit to increase to $\$ 163$ million for $1999 .{ }^{77}$ Those profits are substantially less than the Panamanians require to fund their domestic agenda, enlarge the canal's capacity and combat cross border incursions from Colombia.

The daily operations of the canal have been successfully handled by Panamanians for nearly a decade with great success. The Administrator of the Panama Canal Commission, now called Panama Canal Authority, has been a Panamanian since 1990 and over ninety-eight percent of the 9,500 employees are also Panamanian. Their real challenge will be to maintain the canal and its equipment, much is original equipment nearing 100 years old. Dredging operations are continuous and will have to be increased due to silt deposits if deforestation along the canal banks continues at its current pace. There is a concern that maintenance costs will exceed toll revenues at some point in the future. $^{78}$

There are credible threats to the Panama Canal or United States access to it. The Communist Chinese threat would appear to be indirect in nature with an end goal of supplanting United States influence in Panama and the region with Chinese influence. The Colombian rebels and narco-traffickers have the potential to destabilize Panama and 
sabotage the canal, but to do so overtly would invite United States retaliation and result in a renewed American presence in Panama. That would not facilitate their other goals of dominating Colombia and profit from drug trafficking. Finally, there appears to be legitimate question about the Panamanian government's ability simultaneously to maintain the canal to its current standards and resolve its country's domestic challenges. It is clear that outside assistance, most likely American, will be required for the foreseeable future to aid Panama in these endeavors.

All the identified threats to Panama and the canal will require continuing engagement by the United States. The policy of engagement is endorsed in the 1998 National Security Strategy. It should be a mixture of economic and military engagement aimed at helping Panama to become a more stable democracy with a diversified economy. A failure to do so will increase the danger of the threats to the canal coming to fruition.

\section{CHAPTER THREE ENDNOTES}

${ }^{46}$ Several sources. Dana Rohrabacher, "Should Congress be Concerned about China and the Panama Canal: Yes", Insight, (27 December 1999) emphasizes Communist Chinese threat to canal. Larry Rohter, "Rebel War in Colombia Widening, Pulling in Neighbors", New York Times, (19 September 1999) 
describes the Colombian rebel and narco trafficker threat. "A Reluctant Farewell", Cleveland Plain Dealer, (26 November 1999) depicts numerous threats including Panamanian ineptness.

${ }^{47}$ Larry Rohter, "Rebel War in Colombia Widening, Pulling in Neighbors", New York Times, (19 September 1999).

48 "Panama Canal Blues", Washington Times, (14 December 1999).

${ }^{49}$ Caspar W. Weinberger, "Panama, the Canal and China", Forbes, (4 October 1999) 41.

50 "Weinberger Warns Beijing May Be Eyeing Panama Canal", Associated Press, $(8$ December 1999).

${ }^{51}$ Rowan Scarborough, "China Grabs Power Over Panama Canal”, Washington Times, (12 August 1999).

${ }^{52}$ Qiao Liang and Wang Xiangsui, Unrestricted Warfare, ed. and tran. by Central Intelligence Agency's Foreign Broadcast Information Service, (Beijing: PLA Literature and Arts Publishing House, February 1999).

${ }^{53}$ Dana Rohrabacher, "Should Congress Be Concerned About China and the Panama Canal? Yes”, Insight, (27 December 1999) 40.

${ }^{54}$ Two sources. "Panama Canal", USA Today, (6 October 1999) describes petitions and some of Admiral Moorer's comments. Juanita Darling, "Canal Treaty Foes Say Enemies Have Gained A Beachhead", Los Angeles Times, (18 December 1999) describes the positions of several individuals including Admiral Moorer. 1999).

${ }^{55}$ J. Michael Waller, "China's Beachhead at Panama Canal", Insight on the News, (16 August

${ }^{56}$ J. Michael Waller, "China's Beachhead at Panama Canal", Insight on the News, (16 August 1999).

${ }^{57}$ Several sources. Bruce Fein McLean, "Loyalties and the Canal", Washington Post, (19 November 1999) conjectures on future Chinese invasion of Taiwan and denial of access to canal for U.S. warships. Bill Gertz, "U.S. Secrets Aboard Latest Chinese Sub", Washington Times, (6 December 1999) describes sub under construction and its missiles. "Taiwan Confirms China Building New Nuke Sub", Washington Times, (8 December 1999) writes on purposes for new sub and missiles. Micool Brooke, "Admiral: U.S. Ready For Taiwan Crisis", Associated Press, (14 August 1999) reports U.S. readiness to intervene during Taiwan crisis.

${ }^{58}$ Several sources. Tim McGirk, "Giving Up The Ship?”, Time, (6 September 1999) 48-49, reports claim that Hutchison Whampoa Ltd is an arm of Peoples Liberation Army. Steven Mufson, "In Panama, Ports In A Storm", Washington Post, (8 December 1999) describes pro and con arguments to Li Ka-Shing's ties to Communist Chinese regime. J. Michael Waller, "China's Beachhead at Panama Canal", Insight on the News, (16 August 1999) 20-22, describes Hutchison Whampoa Ltd and Li Ka-Shing's roles with Communist Chinese regime and Peoples Liberation Army.

${ }^{59}$ Two sources. Steven Mufson, "In Panama, Ports In A Storm", Washington Post, 8 December 1999) reports hearings testimony. Bill Gertz, Washinton Times, (12 January 2000) reports Southern Command intelligence report findings and hearings testimony.

60 "Clinton Comfortable with Hutchison in Panama Canal", Reuters, (9 December 1999). 
1999). ${ }^{61}$ Lawrence McQuillan, "Canal Treaties Still Divide U.S. Politics", USA Today, (9 December

62 Joe R. Reeder, "Should Congress Be Concerned About China and the Panama Canal? No", Insight, (27 December 1999).

${ }^{63}$ Ambler Moss, "Panama is Well-Equipped to Handle Canal Takeover", Miami Herald, (14 December 1999).

${ }^{64}$ Two sources. Peter Wonacott, "Hutchison Unit's Panama Canal Contract is Targeted by a U.S. Senate Committee", Wall Street Journal, (15 October 1999) quotes Meredith. Steven Mufson, "In Panama, Ports In A Storm", Washington Post, (8 December 1999) quotes Meredith and gives employee breakdown.

${ }^{65}$ Two sources.Niko Price, "Canal Executives Dispute Takeover By Chinese”, Associated Press, (14 December 1999) gives cargo handling percentages. Joe R. Reeder, "Should Congress Be Concerned About China and the Panama Canal? No", Insight, (27 December 1999) discusses Panama Canal Authority responsibilities.

${ }^{66}$ Two sources, Steven Mufson, "In Panama, Ports in a Storm", Washington Post, (8December 1999) writes about Chinese economic interests in Panama. J. Michael Waller, "China's Beachhead at Panama Canal", Insight on the News, (16 August 1999) reports Chinese ability to coerce in Panama via economic interests.

${ }^{67}$ Serge F. Kovaleski, “Ceremony Marks U.S. Handover of Canal”, Washington Post, (15 December 1999).

${ }^{68}$ Central Intelligence Agency, "World Factbook 1999",URL:<http://www.odci.gov/cia/publications/factbook/us.html>, accessed 21 December 1999.

${ }^{69}$ BG Burgess, J-2 of U.S. Southern Command, discussion of region with Advanced Operational Arts Studies Fellowship in Tampan, Florida on 18 January 2000.

${ }^{70}$ Two sources. David E. Sanger, "Panama Canal Talks", New York Times, (20 October 1999) quotes Moscoso. Tod Robberson, "U.S. Turns Over Last Base in Panama”, Dallas Morning News, (1 December 1999) writes about antidrug center and Moscoso policies.

${ }^{71}$ Larry Rohter, "Rebel War in Colombia Widening, Pulling In Its Neighbors", New York Times, (19 September 1999).

${ }^{72}$ Holger Jensen, "Panama to Take Control of Canal, Ready or Not", Rocky Mountain News, (2 December 1999).

73 "New Alarm Raised About the Canal", Associated Press, (8December 1999).

${ }^{74}$ Two souces. "Panama's Canal", Washington Times, (13 November 1999) writes on lack of motives. Ambler Moss, "Panama is Well-Equipped to Handle Canal Takeover", Miami Herald, (14 December 1999) writes on U.S. reaction to possible threat.

${ }^{75}$ Central Intelligence Agency, "World Factbook 1999", URL: $<$ http://www.odci.gov/cia/publications/factbook/pm.html $>$, accessed 21 Dember 1999.

${ }^{76}$ Tod Robberson, "Looming Absence", Dallas Morning News, (11 December 1999). 
${ }^{77}$ Carla Anne Robbins, "Why Should the U.S. Even Care It's About To Lose Panama Canal?", Wall Street Journal, (10 December 1999).

${ }^{78}$ Mark Falcoff, "Panama: All Alone With a Canal to Maintain", Wall Street Journal, (3 December 1999). 


\section{CHAPTER FOUR}

\section{CONCLUSIONS}

The Panama Canal has been an important interest of the United States for 160 years. Those interests involve economic, military and intangible factors in varying degrees. As the United States enters the twenty-first century, those factors require analysis in determining the relative importance of the national interests residing in the Panama Canal.

The economic interests the United States had in the Panama Canal at the turn of the twentieth century have changed with technological advances in air travel, modern ship building and the global economy. The airplane has supplanted the ship as the primary mode of international passenger travel between the United States and the rest of the world. Seaborne shipping continues to be the mode of choice for movement of cargo between the United States and its overseas trading partners. ${ }^{79}$

Overall, the United States is the largest user of the canal, with approximately seventy percent of the freight passing through the canal either coming from or going to a United States port. The busiest trade routes of the canal are from the United States to the Far East and Europe. Fifteen percent of the United States imports and exports flow through the canal, however those goods account for less than one percent of the nation's Gross Domestic Product. ${ }^{80}$

Most experts have surmised that a closure of the canal would have little effect on the American economy. The popular conception is that American imports and exports would simply find a different route, such as the "land bridge" across the United States. 
The trend toward mega ships is also diminishing the economic influence of the canal because they are simply too large to transit the canal. ${ }^{81}$

The countries of South America, such as Ecuador, Peru and Venezuela have a much larger economic dependence on the canal with forty percent of their seaborne exports transiting the canal. Those nations have no similar "land bridge" to use in the event of a canal closure. ${ }^{82}$ They rely on the United States to keep the canal open.

Mahan theorized that seapower would enable the expansion of the American economy as a maritime nation, much as the same was accomplished by Great Britain. His contemporary, Julian Corbett, would argue control of the sea lines of communications was the primary mission of the fleet. The Panama Canal would qualify as a chokepoint on one of those primary sea lines of communication in the western hemisphere and therefore worthy of defense from an economic standpoint.

The military importance of the canal has degraded with time. The Panama Canal was built at a time when the United States was emerging as a global power and was attempting to have global reach with a "one ocean navy". This required a more timely response than was received during the Spanish-American War with the USS Oregon, which required sixty-nine days to reposition from the Pacific theater to the Atlantic theater. The canal was viewed as a strategic necessity as a lesson learned from that war. ${ }^{83}$ Since then, America has been involved in two world wars and the Cold War, which required global power projection capabilities. Engagement in multiple theaters resulted in the United States development of balanced Atlantic and Pacific Fleets capable of independent action. 
The Chief of Naval Operations, Admiral Jay Johnson, speaking to the United States Army Command and General Staff College on 7 January 2000 said, "The navy is built around twelve carrier battle groups and twelve amphibious ready groups as its primary means of power projection." The aircraft carriers at the heart of that strategy cannot fit through the canal. The navy has found other routes and during 1999 used the canal for less than fifty transits of convenience vice necessity. ${ }^{84}$

The canal is not necessary to United States military operations. Warships that can transit the canal would be vulnerable to terrorist action for the fifty-one mile transit. This includes submarines which must stay surfaced for the transit. The navy ships using the canal are primarily going to or from shipyard facilities or are carrying supplies. The low frequency of American warships using the canal and non-use during recent combat operations highlight the lack of military importance of the canal.

The United States is the leader of the Western Hemisphere and the sole global superpower. The United States has historically rejected foreign involvement over the Panama Canal. That sentiment was well expressed by President Rutherford Hayes, when the French were attempting to build a canal in Panama. He said the "policy of this country is a canal under American control... An interoceanic canal [will be] virtually a part of the coastline of the United States." The United States derived immense national prestige with the opening of the canal and has continuing emotional ties to it as an American possession. Ronald Reagan captured that emotion with his 1976 campaign slogan "We bought it, we built it, we own it." The canal has since passed to Panamanian control, however, the political furor surrounding the December 1999 turnover demonstrates a continuing sense of American pride and interest in the canal. 
The economic and military impact the Panama Canal has on the United States does not justify it being a vital interest worthy of military intervention and possible war to America. The idea of honor as proposed by Thucydides is a reason countries go to war. The United States certainly has honor attached to the canal and continues to view it as an American responsibility. The Neutrality Treaty of 1977 allowing unilateral military intervention by the United States in the event the canal or its neutrality is threatened is proof of that interest.

President Clinton has made it clear through numerous statements and written policy that the United States will insure the canal remains open to international shipping. In a letter he signed for the Panama Canal Turnover Ceremony on 14 December 1999, Clinton vowed "to ensure that it remains open to the world's shipping and commerce." 85 The 1998 National Security Strategy for a New Century said the United States must have global access and freedom of navigation to protect its vital national interests. Mahan would agree and would argue the geograhic position of the United States to the canal makes it an important American interest. McDougall probably summarizes American interest in the Panama Canal best when he writes, "Surely free trade and freedom of the seas are vital interests, and ones the United States ought to promote and, in the latter case, defend with grit because no other navy is up to the job.",86

${ }^{79}$ United States Bureau of Transportation Statistics, URL: $<$ http://www.bts.gov/oai/international/junesum.htm $>$, accessed 30 December 1999.

${ }^{80}$ South America, Central America and the Caribbean 1999, 7th Edition, (London: Europa Publications Ltd) 529. 
${ }^{81}$ United States Department of Transportation, Office of Intermodalism, "The Impacts of Changes in Ship Design on Transportation Infrastructure and Operations", (February 1998),

URL:<http://www.bts.gov/ntt/subjects/ships.html>, accessed 30 December 1999.

${ }^{82}$ Carla Robbins, "Why Should the U.S. Even Care Its About To Lose Panama Canal?", Wall Street Journal, (10 December 1999).

${ }^{83}$ Clifford Krauss, Inside Central America, Its People, Politics and History, (New York: Simon and Schuster, 1991) 252.

${ }^{84}$ Carla Robbins, "Why Should the U.S. Even Care Its About To Lose Panama Canal?", Wall Street Journal, (10 December 1999).

${ }^{85}$ Kevin Galvin, "Clinton Pledges Security for Panama Canal", Ft Worth Star-Telegram, (15 December 1999).

${ }^{86}$ Walter A. McDougall, Promised Land, Crusader State, (New York: Houghton mifflin Company, 1997) 213. 


\section{CHAPTER ONE ENDNOTES}

1 Worldmark Encyclopedia of the Nations, Americas, (Detroit, MI: Gale Press, 1998) 290-291.

2 Panama Canal Treaty, 7 September 1977.

3 Neutrality Treaty, 7 September 1977.

4 Clifford Krauss, Inside Central America, Its People, Politics and History, (New York: Simon and Schuster, 1991) 251.

5 Ibid.

6 Ibid.

7 Ibid,252.

8 A.T. Mahan, The Influence of Seapower upon History, (New York: Hill and Wang, 1957) 29.

9 David McCullough, Path Between the Seas: the Creation of the Panama Canal, 1870-1914, (New York: Simon and Schuster, 1999).

$10 \mathrm{Ibid}, 254-255$.

$11 \mathrm{Ibid}, 257$.

$12 \mathrm{Ibid}, 257-258$.

13 Panama Canal and Neutrality Treaties, 7September 1977. See also John Major, Prize Possession: the United States and the Panama Canal, 1903-1979, (London: Cambridge University Press, 1993) 349-350.

14 South America. Central America and the Caribbean 1999, 7th Edition, (London: Europa Publications Ltd.) 529.

$15 \mathrm{Ibid}, 255$.

\section{CHAPTER TWO ENDNOTES}

16 United States Marine Corps, Panama Country Handbook (1999).

17 Denison Kitchel, The Truth About the Panama Canal, (New Rochelle, NY: Arlington House, 1978) $140-141$.

18 Ibid,255.

19 Carla Anne Robbins, "Why Should The U.S. Even Care Its About To Lose Panama Canal?, Wall Street Journal, (10 December 1999).

20 South America, Central America and the Caribbean 1999, 7th Edition, (London: Europa Publications Ltd.) 529.

21 Caspar W. Weinberger, "Panama, the Canal and China", Forbes, (4 October 1999) 41. 
22 Panama Canal Commission, "Maritime Operations", URL:<http://www.pancanal.com $>$, accessed 27 August 1999.

23 Central Intelligence Agency, "The World Factbook, 1999", URL: $<$ http://www.odci.gov/cia/publications/factbook/us.html>, accessed 21 December 1999.

24 “A Reluctant Farewell", Cleveland Plain Dealer, (26 November 1999).

25 United States Bureau of Transportation Statistics, URL:<http://www.bts.gov/oai/international/junesum.htm>, accessed 30 December 1999.

26 United States Department of Transportation, URL: $<$ http://www trans-inst.org/1.html $>$, accessed 30 December 1999.

27 United States Department of Transportation, Office of Intermodalism, "The Impacts of Changes in Ship Design on Transportation Infrastructure and Operations", (February 1998), URL:<http://www.bts.gov/ntl/subjects/ships.html, accessed 30 December 1999.

28 South America, Central America and the Caribbean, 1999, 7th Edition, (London: Europa Publications Ltd) 529.

29 United States Department of Transportation, Office of Intermodalism, "The Impacts of Changes in Ship Design on Transportation Infrastructure and Operations", (February 1998), URL:<http://www.bts.gov/ntl/subjects/ships.html, accessed 30 December 1999.

30 South America, Cenral America and the Caribbean, 1999, 7th Edition, (London: Europa Publications Ltd.) 529.

31 Carla Robbins, "Why Should the United States Even Care Its About To Lose Panama Canal?", Wall Street Journal, (10 December 1999).

32 A.T.Mahan, The Influence of Seapower upon History, (New York: Hill and Wang, 1957) 29.

33 George E Stanford Jr, "Strategic Passages", Naval Ocean Research and Development Activity, Requirements and Assessments Office, (October 1987).

34 The White House, National Security Strategy for a New Century, (October 1998) 27.

35 Julian S. Corbett, Some Priciples of Maritime Strategy, (Anapolis, Maryland: Naval Institute Press, 1988) 322.

36 Carla Robbins, "Why should the U.S. Even Care Its About to Lose Panama Canal?", Wall Street Journal, (10 December 1999).

37 United States Navy, URL:<http://www.chinfo.navy.mil/navypalib/factfile/ships, accessed 30 December 1999.

38 Admiral Jay Johnson, CNO of United States Navy, Address to Command and General Staff College, given at Ft Leavenworth, Kansas on 7 January 2000.

39 Thucydides, History of the Peloponnesian War, (London: Penguin Books, 1972). 1999).

40 Linda Robinson, "Yankees Go Home, Finally", U.S. News and World Report, (6 December 
41 J. Michael Hogan, The Panama Canal in American Politics, (Champaign, Illinois: Southern Illinois University Press, 1986) 7.

42 Steven Mufson, "In Panama, Ports in a Storm", Washington Post, (8 December 1999).

43 Clifford Krauss, Inside Central America, its People, Politics and History, (New York: Simon and Schuster, 1991) 255.

44 Walter A. McDougal, Promised Land, Crusader State, (New York: Houghton Mifflin Company, 1997) 213 .

45 Justin Brown, "World Chokepoints are Moving from Sea to Air", Christian Science Monitor, (15 December 1999).

\section{CHAPTER THREE ENDNOTES}

46 Several sources. Dana Rohrabacher, "Should Congress be Concerned about China and the Panama Canal: Yes", Insight, (27 December 1999) emphasizes Communist Chinese threat to canal. Larry Rohter, "Rebel War in Colombia Widening, Pulling in Neighbors", New York Times, (19 September 1999) describes the Colombian rebel and narco trafficker threat. "A Reluctant Farewell", Cleveland Plain Dealer, (26 November 1999) depicts numerous threats including Panamanian ineptness.

47 Larry Rohter, "Rebel War in Colombia Widening, Pulling in Neighbors", New York Times, (19 September 1999).

48 “Panama Canal Blues", Washington Times, (14 December 1999).

49 Caspar W. Weinberger, "Panama, the Canal and China", Forbes, (4 October 1999) 41.

50 "Weinberger Warns Beijing May Be Eyeing Panama Canal", Associated Press, $(8$ December 1999).

51 Rowan Scarborough, "China Grabs Power Over Panama Canal", Washington Times, (12 August 1999).

52 Qiao Liang and Wang Xiangsui, Unrestricted Warfare, ed. and tran. by Central Intelligence Agency's Foreign Broadcast Information Service, (Beijing: PLA Literature and Arts Publishing House, February 1999).

53 Dana Rohrabacher, "Should Congress Be Concerned About China and the Panama Canal? Yes", Insight, (27 December 1999) 40.

54 Two sources. "Panama Canal", USA Today, (6 October 1999) describes petitions and some of Admiral Moorer's comments. Juanita Darling, "Canal Treaty Foes Say Enemies Have Gained A Beachhead", Los Angeles Times, (18 December 1999) describes the positions of several individuals including Admiral Moorer. 1999).

55 J. Michael Waller, "China's Beachhead at Panama Canal", Insight on the News, (16 August

56 J. Michael Waller, "China's Beachhead at Panama Canal", Insight on the News, (16 August 1999).

57 Several sources. Bruce Fein McLean, "Loyalties and the Canal", Washington Post, (19 November 1999) conjectures on future Chinese invasion of Taiwan and denial of access to canal for U.S. 
warships. Bill Gertz, "U.S. Secrets Aboard Latest Chinese Sub", Washington Times, (6 December 1999) describes sub under construction and its missiles. "Taiwan Confirms China Building New Nuke Sub", Washington Times, (8 December 1999) writes on purposes for new sub and missiles. Micool Brooke, "Admiral: U.S. Ready For Taiwan Crisis", Associated Press, (14 August 1999) reports U.S. readiness to intervene during Taiwan crisis.

58 Several sources. Tim McGirk, "Giving Up The Ship?”, Time, (6 September 1999) 48-49, reports claim that Hutchison Whampoa Ltd is an arm of Peoples Liberation Army. Steven Mufson, "In Panama, Ports In A Storm", Washington Post, (8 December 1999) describes pro and con arguments to Li Ka-Shing's ties to Communist Chinese regime. J. Michael Waller, "China's Beachhead at Panama Canal", Insight on the News, (16 August 1999) 20-22, describes Hutchison Whampoa Ltd and Li Ka-Shing's roles with Communist Chinese regime and Peoples Liberation Army.

59 Two sources. Steven Mufson, "In Panama, Ports In A Storm", Washington Post, (8 December 1999) reports hearings testimony. Bill Gertz, Washinton Times, (12 January 2000) reports Southern Command intelligence report findings and hearings testimony.

60 "Clinton Comfortable with Hutchison in Panama Canal", Reuters, (9 December 1999). 1999).

61 Lawrence McQuillan, "Canal Treaties Still Divide U.S. Politics", USA Today, (9 December

62 Joe R. Reeder, "Should Congress Be Concerned About China and the Panama Canal? No", Insight, (27 December 1999).

63 Ambler Moss, "Panama is Well-Equipped to Handle Canal Takeover”, Miami Herald, (14 December 1999).

64 Two sources. Peter Wonacott, "Hutchison Unit's Panama Canal Contract is Targeted by a U.S. Senate Committee", Wall Street Journal, (15 October 1999) quotes Meredith. Steven Mufson, "In Panama, Ports In A Storm", Washington Post, (8 December 1999) quotes Meredith and gives employee breakdown.

65 Two sources.Niko Price, "Canal Executives Dispute Takeover By Chinese", Associated Press, (14 December 1999) gives cargo handling percentages. Joe R. Reeder, "Should Congress Be Concerned About China and the Panama Canal? No", Insight, (27 December 1999) discusses Panama Canal Authority responsibilities.

66 Two sources, Steven Mufson, "In Panama, Ports in a Storm", Washington Post, (8December 1999) writes about Chinese economic interests in Panama. J. Michael Waller, "China's Beachhead at Panama Canal", Insight on the News, (16 August 1999) reports Chinese ability to coerce in Panama via economic interests.

67 Serge F. Kovaleski, “Ceremony Marks U.S. Handover of Canal”, Washington Post, (15 December 1999).

68 Central Intelligence Agency, "World Factbook 1999",URL:<http://www.odci.gov/cia/publications/factbook/us.html>, accessed 21 December 1999.

69 BG Burgess, J-2 of U.S. Southern Command, discussion of region with Advanced Operational Arts Studies Fellowship in Tampan, Florida on 18 January 2000.

70 Two sources. David E. Sanger, "Panama Canal Talks", New York Times, (20 October 1999) quotes Moscoso. Tod Robberson, "U.S. Turns Over Last Base in Panama", Dallas Morning News, (1 December 1999) writes about antidrug center and Moscoso policies. 
71 Larry Rohter, "Rebel War in Colombia Widening, Pulling In Its Neighbors", New York Times, (19 September 1999).

72 Holger Jensen, "Panama to Take Control of Canal, Ready or Not", Rocky Mountain News, (2 December 1999).

73 "New Alarm Raised About the Canal", Associated Press, (8December 1999).

74 Two souces. "Panama's Canal", Washington Times, (13 November 1999) writes on lack of motives. Ambler Moss, "Panama is Well-Equipped to Handle Canal Takeover", Miami Herald, (14 December 1999) writes on U.S. reaction to possible threat.

75 Central Intelligence Agency, "World Factbook 1999", URL:<http://www.odci.gov/cia/publications/factbook/pm.html>, accessed 21 Dember 1999.

76 Tod Robberson, "Looming Absence", Dallas Morning News, (11 December 1999).

77 Carla Anne Robbins, "Why Should the U.S. Even Care It's About To Lose Panama Canal?", Wall Street Journal, (10 December 1999).

78 Mark Falcoff, "Panama: All Alone With a Canal to Maintain", Wall Street Journal, (3 December 1999).

\section{CHAPTER FOUR ENDNOTES}

79 United States Bureau of Transportation Statistics, URL:<http://www.bts.gov/oai/international/junesum.htm>, accessed 30 December 1999.

80 South America, Central America and the Caribbean 1999, 7th Edition, (London: Europa Publications Ltd) 529.

81 United States Department of Transportation, Office of Intermodalism, "The Impacts of Changes in Ship Design on Transportation Infrastructure and Operations", (February 1998), URL:<http://www.bts.gov/ntl/subjects/ships.html>, accessed 30 December 1999.

82 Carla Robbins, "Why Should the U.S. Even Care Its About To Lose Panama Canal?", Wall Street Journal, (10 December 1999).

83 Clifford Krauss, Inside Central America, Its People, Politics and History, (New York: Simon and Schuster, 1991) 252.

84 Carla Robbins, “Why Should the U.S. Even Care Its About To Lose Panama Canal?", Wall Street Journal, (10 December 1999). December 1999).

85 Kevin Galvin, "Clinton Pledges Security for Panama Canal", Ft Worth Star-Telegram, (15

86 Walter A. McDougall, Promised Land, Crusader State, (New York: Houghton mifflin Company, 1997) 213. 


\section{BIBLIOGRAPHY}

Associated Press, Weinberger Warns Beijing Maybe Eyeing Panama Canal. 8 December 1999.

. New Alarm Raised About the Canal. 8 December 1999.

Brooks, Michael. Admiral: U.S. Ready for Taiwan Crisis. Pacific Stars and Stripes, 14 August 1999.

Brown, Justin. World Chokepoints are Moving from Sea to Air. Christian Science Monitor, 15 December 1999.

Central Intelligence Agency, "The World Factbook, 1999", URL: <http://www.odci.gov/cia/publications/factbook/us.html $>$; Internet; accessed 21 December 1999.

Clausewitz, Carl Von. On War, ed. and trans. by Michael Howard and Peter Paret, Princeton: Princeton University Press, 1976.

Cleveland Plain Dealer, A Reluctant Farewell. 26 November 1999.

Conaway, Janelle. Savvy Navigator of a Turbulent Canal. Americas, January/February 1999.

Corbett, Julian. Some Principles of Maritime Strategy. London: Longmans, Green and Co., 1911.

Darling, Juanita. Canal Treaty Foes Say Enemies Have Gained a Beachhead. Los Angeles Times, 18 December 1999.

Falcoff, Mark. The Americas: Let Panama Try Life Without a U.S. Presence. Wall Street Journal, 13 November 1999.

. Panama: All Alone With a Canal to Maintain. Wall Street Journal, 3 December 1999.

Friedman, Norman. Revisiting the Two-Ocean Navy. United States Naval Institute Proceedings, February 1997.

Galvin, Kevin. Clinton Pledges Security for Panama Canal. Ft Worth Star-Telegram, 15 December 1999. 
Gertz, Bill. U.S. Secrets Aboard Latest Chinese Sub. Washington Times, 6 December 1999.

. China Called a Threat at Canal. Washington Times, 12 January 2000.

Griffith, Ivelaw L. Caribbean Geopolitics and Geonarcotics: New Dynamics, Same Old Dilemma. Naval War College Review, Spring 1998.

Hammond, James W. Jr. We are Products of 1898. United States Naval Institute Proceedings, August 1998.

Hasenauer, Heike. The Canal - a Historic Shortcut. Soldiers, July 1999.

Hogan, J. Michael. The Panama Canal in American Politics. Champaign, IL: Southern Illinois University Press, 1986.

Holden, Robert H. Securing Central America Against Communism: the United States and the Modernization of Surveillance in Cold War. Journal of Interamerican Studies and World Affairs, Spring 1999.

Jensen, Holger. Panama to Take Control of Canal, Ready or Not. Rocky Mountain News, 2 December 1999.

Kitchel, Denison. The Truth About the Panama Canal. New Rochelle, NY: Arlington House, 1978.

Komorowski, Raymond R. Death Knell of the Panama Canal? Naval War College Review, Winter 1999.

Kovaleski, Serge F. Ceremony Marks U.S. Handover of Canal. Washington Post, 15 December 1999.

Krauss, Clifford. Inside Central America, Its People, Politics and History. New York: Simon and Schuster, 1991.

Liang, Qiao and Wang Xiangsui. Unrestricted Warfare, ed. and tran. by Central Intelligence Agency's Foreign Broadcast Information Service. Beijing: PLA Literature and Arts Publishing House, February 1999.

Mahan, A.T. The Influence of Seapower Upon History. New York: Hill and Wang, 1957.

Major, John. Prize Possession: the United States and the Panama Canal, 1903-1979. London: Cambridge University Press, 1993. 
McCollough, David. Path Between the Seas: the Creation of the Panama Canal, 18701914. New York: Simon and Schuster, 1999.

McDougall, Walter A. Promised Land, Crusader State. New York: Houghton Mifflin Co., 1997.

McGirk, Tom. Giving Up the Ship? Time, 6 September 1999.

McLean, Bruce Fein. Loyalties and the Canal. Washington Post, 19 November 1999.

McQuillan, Lawrence. Canal Treaties Still Divide U.S. Politics. USA Today, 9 December 1999.

Morton, Robert. As U.S. Leaves Panama Canal, China Moves In. Insight on the News, 5-12 April 1999.

Moss, Ambler. Panama is Well Equipped to Handle Canal Takeover. Miami Herald, 14 December 1999.

Mufson, Steven. In Panama, Ports in a Storm. Washington Post, 8 December 1999.

Neutrality Treaty, 7 September 1977.

Oliver, Edward G. Panama: Confrontation with China? The Officer, December 1998.

Panama Canal Commission, "Maritime Operations", URL: $<$ http://www.pancanal.com>; Internet; accessed 27 August 1999.

Paret, Peter, ed. by. Makers of Modern Strategy from Machiavelli to the Nuclear Age. Princeton: Princeton University Press, 1986.

Reeder, Joe R. Should Congress Be Concerned About China and the Panama Canal? No. Insight, 27 December 1999.

Reuters, Clinton Comfortable with Hutchison in Panama Canal. 9 December 1999.

Robberson, Tod. U.S. Turns Over Last Base in Panama. Dallas Morning News, 1 December 1999. Looming Absence. Dallas Morning News, 11 December 1999.

Robbins, Carla. Why Should U.S. Even Care Its About to Lose Panama Canal? Wall Street Journal, 10 December 1999. 
Robinson, Linda. Yankees Go Home, Finally. U.S. News and World Report, 6 December 1999.

Rohrabacher, Dana. Should Congress be Concerned About China and the Panama Canal? Yes. Insight, 27 December 1999.

Rohter, Larry. As Panama Canal Transfer Nears, More Jockeying to Fill a Power Vacuum. New York Times, 5 October 1997.

. Heavy Hand of Beijing Dampens a Panama Canal Fest. New York Times, 8 September 1997.

. Handoff in Panama: Hong Kong was Just a Rehearsal. New York Times, 13 July 1997.

. Pullout From Panama and Venezuelan Reluctance Leave Gap in U.S. Air

War on Drugs. New York Times, 14 August 1999.

. Rebel War in Colombia, Pulling in Neighbors. New York Times, 19 September 1999.

Sanger, David E. Panama Canal Talks. New York Times, 20 October 1999.

Scarborough, Rowan. China Grabs Power Over Panama Canal. Washington Times, 12 August 1999.

- U.S. Wouldn't Let China Close Panama Canal. Washington Times, 13 August 1999.

Silverstein, Gordon. Reversing Course: Carter's Foreign Policy Domestic Politics and the Failure of Reform. The American Political Science Review, June 1998.

South America, Central America and the Caribbean 1999, 7th Ed. London: Europa Publications Ltd. 1999.

Stanford, George E Jr. Strategic Passages. Naval Ocean Research and development Activity, Requirements and Assessments Office, October 1987.

Thucydides. History of the Peloponnesian War. New York: Penguin Books, 1954.

USA Today, Panama Canal. 6 October 1999.

U.S. Department of Transportation Statistics, URL:<http://www.bts.gov/oai/international/junesum.htm>; Internet; accessed 30 December 1999. 
U.S. Department of Transportation, URL:<http://www.trans-inst.org/1.html>; Internet; accessed 30 December 1999.

U.S. Department of Transportation, Office of Intermodalism, "The Impacts of Changes in Ship Design on Transportation Infrastructure and Operations", URL: <http://www.bts.gov/ntl/subjects/ships.html>; Internet; accessed 30 December 1999.

U.S. Marine Corps, Panama Country Handbook. 1999.

U.S. Navy, URL: $<$ http://www.chinfo.navy.mil/navypalib/factfile/ships $>$; Internet; accessed 30 December 1999.

Waller, J. Michael. China's Beachhead at Panama Canal. Insight on the News, 16 August 1999.

Washington Times, Taiwan Confirms China Building New Nuke Sub. 8 December 1999. . Panama's Canal. 13 November 1999. , Panama Canal Blues. 14 December 1999.

Weinberger, Caspar W. Panama, the Canal and China. Forbes, 4 October 1999.

White House. A National Security Strategy For a New Century. October 1998.

Wonacott, Peter. Hutchison Unit's Panama Canal Contract is Targeted by a U.S. Senate Committee. Wall Street Journal, 15 October 1999.

Wooster, Martin Morse. Sounding Taps in Panama. The American Enterprise, September/October 1998.

Worldmark Encyclopedia of the Nations, Americas. Detroit: Gale Press, 1998. 